\title{
Pemenuhan Hak Anak dalam Keluarga Poligami
}

\section{Children Right Fulfillment in Polygamy Family}

\author{
Ratna Kusuma Wardani ${ }^{1^{*}}$, Idaul Hasanah ${ }^{2^{*}}$
}

${ }^{1,22}$ Jurusan Syariah Universitas Muhammadiyah Malang, Jln. Raya Tlogomas no. 246, Malang 65144. Email :ratna1924@gmail.com

\begin{abstract}
Abstrak. Akar dari munculnya persoalan-persoalan anak kebanyakan adalah karena ketidakmampuan keluarga dalam membangun kebahagiaan dan kesejahteraan dalam kehidupannya. Oleh karena itu, persoalan poligami sesungguhnya bukan terkait dengan hubungan antara suami dan istri saja, tetapi yang lebih penting adalah bagaimana anak tetap dapat mengembangkan potensinya dalam kedewasaan dan kemandiriannya. Kenyataannya secara umun tidak semua anak yang ada dalam keluarga poligami mendapatkan hak yang seharusnya didapatkan, bahkan ada yang tidak terpenuhi. Hal tersebut terjadi karena kualitas hubungan yang menurun tajam setelah poligami antara orang tua dan anak terutama antara ayah dan anak.
\end{abstract}

Kata kunci : keluarga poligami, pemenuhan hak anak

Abstract. Root of the children problems is the family incapability in build up a happiness and prosperity in their life. Therefore, polygamy problem is not only related to wife and husband but the most important is also how the children can still develop their potential in their adulthood and independent. In fact, not all children in polygamy family get what they should get, even there is unfulfilled. It happens after polygamy, because the decrease of relationship between parents and children especially father and children.

Key words: polygamy family, children right fulfillment.

\section{Pendahuluan}

Anak secara alamiah adalah makhluk yang masih dalam tanggung jawab orang tuanya secara langsung. Anak memiliki hak-hak yang harus dipenuhi khususnya bagi orang tuanya. Dalam kondisi normal, artinya anak yang tumbuh dalam keluarga lengkap kedua orang tuanya, dan bertanggung jawab penuh memenuhi kebutuhan tumbuh kembang anak -sedikit banyak- hak-hak tersebut akan terpenuhi. Namun ada banyak kondisi yang menyebabkan hak-hak anak tidak terpenuhi misalnya kelalaian orang tua, meninggalkan orang tua, kurangnya pengetahuan dan pendidikan orang tua, persoalan ekonomi dan sebagainya. Belum lagi penyakit-penyakit keluarga seperti perceraian, perselingkuhan, perzinaan, dan sebagainya memiliki andil yang besar pula dalam menciptakan keterlantaran anak. Untuk itu tanggung jawab terhadap anak sebagai generasi penerus bangsa tidak hanya tanggung jawab orang tua saja, namun merupakan tanggung jawab publik termasuk pemerintah.

Upaya perlindungan anak di Indonesia telah banyak dilakukan oleh pemerintah melalui beberapa undang-undang. Hal ini dilakukan berdasarkan pertimbangan bahwa Negara menjamin kesejahteraan tiap warganya dan termasuk anak di dalamya. Anak adalah amanah dan karunia Tuhan yang dalam dirinya melekat harkat dan martabat sebagai manusia seutuhnya. Agar setiap anak kelak dapat tumbuh secara optimal baik fisik, mental, maupun sosial serta berakhlak mulia. Maka perlu dilakukan upaya perlindungan serta upaya mewujudkan kesejahteraan anak dengan memberikan jaminan terhadap pemenuhan haknya serta perlakuan tanpa diskriminasi. Dalam hal ini, Pemerintah Indonesia telah mengelurkan kebijakan tentang upaya perlindungan anak, salah satunya adalah UU RI No. 23 Tahun 2002 tentang Perlindungan Anak. Pada pasal 3 (tiga) dari UU tersebut dikatakan bahwa perlindungan anak bertujuan untuk menjamin terpenuhinya hak-hak anak agar dapat tumbuh, berkembang, dan berpartisipasi secara optimal sesuai dengan harkat dan martabat kemanusiaan, serta mendapat perlindungan dari kekerasan dan diskriminasi, demi terwujudnya anak Indonesia yang berkualitas, berakhlak mulia, dan sejahtera. 
Salah satu akar penyebab munculnya persoalan anak -yang salah satunya tidak terpenuhi hak-haknya adalah karena ketidakmampuan keluarga dalam membangun kebahagiaan dan kesejahteraan dalam kehidupannya. Dalam keluarga normal, kedua orang tua lengkap punya kesadaran penuh terhadap tanggung jawabnya sebagai orang tua, hak anak terpenuhi. Yang menjadi pertanyaan bagaimana pemenuhan hak anak dalam keluarga poligami?

Sebagaimana diketahui perkawinan poligami sendiri dalam kontek kehidupan masyarakat di indonesia sudah menimbulkan masalah. Tidak semua masyarakat menerima sebagai sebuah kenyataan dan kebolehan dalam agama. Begitu pula secara yuridis, untuk berpoligami harus melalui tahap-tahap yang lebih panjang dari pada pernikahan biasa. Seperti ijin poligami melalui pengadilan, ijin isteri pertama dan sebagainya.

Dalam kehidupan berkeluarga dimana sang ayah yang berpoligami harus membagi perhatian untuk lebih dari satu keluarga, dua isteri (atau lebih), anak dari isteri yang berbeda, beban nafkah yang lebih tinggi, tuntutan perhatian dan pemenuhan hak anak juga lebih tinggi. Belum lagi ketika poligami dilakukan dengan timbulnya masalah terlebih dulu. Bagaimana pemenuhan hak anak-anaknya?

Sebuah penelitian mengungkap bahwa poligami membawa dampak buruk bagi perkembangan jiwa anak, terutama bagi anak perempuan. Penelitian yang dilakukan oleh Mudhofar Badri tersebut mengungkapkan temuan yang memprihatinkan, bahwa perkawinan poligami menimbulkan beban psikologis yang berat bagi anak-anak. Timbul rasa minder dan menghindar bergaul dengan teman sebayanya dan bahkan bagi anak perempuan biasanya sulit bergaul dengan teman laki-lakinya. Hal tersebut akan berdampak pada psikologis anak yang kemudian berdampak pula pada cara berpikirnya kelak. Akibat lanjut dari tekanan psikologis bagi anak tersebut adalah melemahnya kondsi fisik sehingga mereka mudah terserang berbagai penyakit.

Di sisi lain UU Perkawinan maupun PP 10 tahun 1983 mengenai poligami tidak mensyaratkan ijin bagi ayahnya untuk melakukan poligami, ijin hanya berlaku bagi isteri pertamanya. Hal ini memperlihatkan bahwa anak belum/tidak menjadi aspek yang diperhatikan dalam peraturan poligami.Tampaknya masih perlu dilakukan revisi peraturan terkait untuk memperketat peraturan khususnya tentang hak anak, sehingga pelaku poligami yang mengakibatkan anak menjadi terlantar bisa ditindak Negara. Meskipun di sisi lain tidak tertutup kemungkinan bahwa ada pula kasus-kasus poligami yang justru meningkatkan hak anak dan memberikan perlindungan bagi anak, misalnya poligami dengan tujuan melindungi anak-anak yatim dengan catatan tidak mengabaikan hak istri pertama dan anak-anak kandungnya sendiri. Seorang laki-laki yang melakukan poligami memiliki tanggung jawab untuk memenuhi semua kewajibannya sebagai seorang suami dan ayah yang baik pada para istri, anak kandung, maupun anak tirinya.

\section{Hasil dan Pembahasan \\ Hasil}

Hak anak adalah segala sesuatu yang harus didapatkan atau diterima oleh anak dan apabila tidak diperoleh, anak berhak menuntut hak tersebut. Dalam hal ini yang wajib memenuhi, menjamin serta melindungi adalah orang tua, keluarga, masyarakat dan pemerintah. Dalam suatu keluarga hal yang perlu diperhatikan oleh orang tua dalam memperhatikan hak anak untuk masa depan mereka yaitu hak menyusui, hak untuk mendapatkan asuhan, hak untuk mendapatkan nama baik dan kewarganegaraan, hak nafkah atau harta, hak pengajaran, serta hak pendidikan, akhlak dan agama. (Subhi Mahmasani. 1993: 203). Beberapa hal tentang ahwal syakhshiyyah yang membahas tentang hak-hak anak dalam islam yaitu nasab, radha', hadhanah, perwalian dan nafkah. (Wahbah Zuhaili. 2011: 25).

Jalan pintas dalam melakukan poligami melalui pernikahan di bawah tangan atau hidup bersama tanpa ikatan pernikahan dianggap lebih mudah daripada mengajukan permohonan berpoligami ke pengadilan dengan prosedur yang lebih rumit. Alternative menikah siri yang memenuhi kaidah agama, tetapi tidak diakui secara hukum, dianggap sebagai jalan keluar termudah. Tanpa disadari, melalui pernikahan siri, seorang perempuan tidak memperoleh perlindungan hukum atas ikatan perkawinan yang dilakukannya. Suatu perkawinan yang tidak dicatatkan pada kantor pencatatan nikah, baik pada Kantor Catatan Sipil atau Kantor Urusan Agama, dianggap tidak sah oleh agama meskipun sebenarnya perkawinan tersebut sudah sah menurut agama. Apabila ini terjadi, yang paling dirugikan tentu saja pihak perempuan 
dan anak yang dilahirkan, karena perkawinan yang telah dilakukan dianggap tidak pernah terjadi oleh Negara. Implikasinya bahwa segala konsekuensi akibat perkawinan tersebut juga dianggap tidak pernah ada, seperti hak waris dan sebagainya.

Nafkah anak hukumnya wajib karena merupakan hak anak yang wajib diberikan oleh orang tua berdasarkan firman Allah SWT dalam surat Al-Baqarah (2): 233

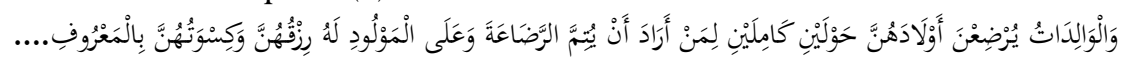

"Dan ibu-ibu hendaklah menyusui anak-anaknya selama dua tahun penuh, bagi yang ingin menyusui secara sempurna. Dan kewajiban ayah menanggung nafkah dan pakaian mereka dengan cara yang patut.."

Dalam ayat tersebut mengandung arti bahwa seorang ayah harus menanggung nafkah anaknya karena sebab kelahiran, sebagaimana wajibnya nafkah atas istri karena ia melahirkan anak tersebut.Oleh karena nafkah adalah salah satu hak anak yang harus dipenuhi oleh orang tua dimana hal tersebut merupakan kewajiban ayah untuk memenuhinya. Biaya nafkah anak tidak hanya menyangkut biaya sandang, pangan, dan tempat tinggal anak semata, akan tetapi juga biaya pendidikan anak. Pendidikan ini penting disebabkan dalam ajaran Islam anak merupakan generasi pemegang tongkat estafet perjuangan dan khalifah di muka bumi. (Nizam. 2005: 26-27). Jadi biaya pendidikan merupakan hal pokok bagi anak yang harus terpenuhi terlepas dari biaya sandang, pangan dan papan. Karena di Negara kita Indonesia, anak wajib belajar dua belas tahun tahun disamping merupakan kewajiban seorang manusia yang beragama Islam untuk selalu menuntut ilmu sepanjang hidup.

Mayoritas ulama selain Hanabilah, dalam masalah nafkah anak tidak mensyaratkan harus seagama, dalilnya firman Allah SWT:

Yang artinya,”...Dan kewajiban ayah menanggung nafkah dan pakaian mereka dengan cara yang patut..."(QS. Al-Baqarah: 233)

Ayat ini menunjukkan bahwa kelahiranlah yang menyebabkan wajibnya nafkah anak atas ayahnya, baik seagama maupun tidak. Karena nafkah adalah penyambung hidup seseorang, sedangkan hidup itu sangat urgen meskipun atas diri seorang kafir. Dan lagi, pada hakikatnya harta itu tidak begitu penting karena Allah juga member rezeki kepada orang Mukmin dan juga kepada orang kafir. Mengenai siapa yang berkewajiban menanggung nafkah anak, para fuqaha sepakat jika ayah masih mampu bekerja dan termasuk kaya, menurut mayoritas ulama maka ia sendiri berkewajiban menanggung nafkah anak-anaknya, tanpa dibantu oleh orang lain. Ayat tersebut juga menyebutkan pengkhususan nafkah untuk anak karena termasuk bagia dari ayah, sehingga memberi nafkah kepada anak sama seperti member nafkah untuk diri sendiri. (Wahbah Zuhaili. 2011: 137-139).

Dalam salah satu kasus poligami yang pernah diteliti dimana anak tidak mendapatkan nafkah sepenuhnya dari ayah setelah poligami dan bahkan ayah tidak dapat menafkahi keluarga seutuhnya dikarenakan peran ayah atau suami secara materi tidak mampu untuk memenuhi kebutuhan nafkah keluarga tanpa adanya kesadaran dalam dirinya, dilihat dari perubahan pemberian nafkah sebelum dan sesudah poligami. Ayah cenderung memilih istri kedua bahkan lebih memilih tinggal selamanya dengan istri kedua dan meninggalkan anak-anaknya dengan istri pertama. Sehingga hak anak kurang mendapat perhatian dari ayah. Ada juga dalam kasus poligami dimana ayah tetap memenuhi hak nafkah anak setelah poligami dengan baik dan sepenuhnya tanpa adanya perbedaan sebelum dan setelah poligami. Dan pula tak jarang bahwa poligami setelah perceraian pun mendapat sorotan ketika kewajiban ayah kadung gugur dan tergantikan oleh ayah tiri. Sehingga untuk dapat mengetahui bahwa hak anak akan dapat terpenuhi jika mencakup indikator terpenuhinya hak nafkah terhadap anak meliputi pangan, sandang, papan dan biaya pendidikan. Hal tersebut berlaku bagi anak dalam keluarga monogami ataupun poligami. Akan tetapi, butuh perhatian khusus terhadap anak yang berada dalam keluarga poligami, karena apabila suami tidak dapat berlaku adil maka yang menjadi korban adalah anak. Akan lebih baik jika suami tidak merubah perhatian dan kualitas hubungannya dengan anak, terlebih lagi mengenai nafkah. Sehingga dapat disimpulkan bahwa kesuksesan dan tercapainya kebahagian dalam berpoligami apabila suami memahami akan kewajibannya terhadap keluarga terutama anak. 
Kerap terjadi permasalahan mengenai hak anak dalam keluarga poligami yang berhubungan dengan pemberian nafkah yang tidak adil serta berkurangnya perhatian dan kasih sayang oleh suami terhadap anak, terlepas dari relasi antara suami dan istri. Maka dari itu perlu diperhatikan pemahaman mengenai poligami dalam islam oleh suami sebelum memutuskan untuk berpoligami. Karena secara tidak langsung akan mempengaruhi pula sikap terhadap anak.

Tanggung jawab orang tua dalam memenuhi kebutuhan anak tidak boleh sampai lengah meskipun hanya salah satu dari orang tua tersebut yang mampu untuk memenuhinya dikarenakan beberapa alasan, terlepas dari itu semua jangan sampai kebutuhan dan hak anak jadi terabaikan oleh permasalahan kedua orang tua. Dalam kehidupan berpoligami pun demikian, adapun perubahan yang terjadi setelah kehidupan berpoligami, tidak mempengaruhi pemenuhan hak anak dalam mewujudkan kehidupan anak yang lebih baik dan layak.

Dalam hal perwalian atas diri seseorang, kewenangan wali atas diri seseorang tersebut adalah mendidik dan mengajar, menjaga kesehatan, mengawasi perkembangan fisik, menyekolahkan, dan mengurus pernikahannya. Dalam hal perwalian atas harta benda, jika anak yang diwalikan itu mempunyai harta maka sang ayah berhak mengurus dan mengembangkan hartanya, menurut kesepakatan ulama empat madzhab. Maka dari itu, anak yang belum baligh dan belum mampu untuk melakukan perbuatan hukum sangat mennbutuhkan wali utuk mengurus dirinya pribadi dan hartanya. Sehingga perwalian merupakan hak anak yang tidak boleh terabaikan karena merupakan suatu hal yang mempengaruhi perkembangan hidupnya kelak. Perwalian dan hadhanah tidak dapat terpisahkan jika mereka adalah orang tua dari anak. (Wahbah Zuhaili. 2011: 82-84). Kuantitas pertemuan antara orangtua dan anak usia dini sangat diutamakan dari pada kualitasnya. Jika anak sudah tumbuh remaja, kualitas pertemuanlah yang punya peranan penting. (Munif Chatib. 2013: 44).

Kualitas pertemuan antara anak dengan ayah mempengaruhi pola komunikasi, kedekatan dan keteladanan terhadap anak dimana hal tersebut berpengaruh besar tehadap perwalian. Seorang ayah hendaknya memperhatikan kualitas hubungannya dengan anak dan tetap mempertahankannya bahkan setelah poligami, meskipun secara kuantitas akan sangat bebeda dengan sebelum poligami akibat dari pembagian waktu dengan beberapa istri. Jika seorang poligan tidak memperhatikan hak tersebut, maka akan sangat berpengaruh pada hak perwalian anak yang di dalamnya terdapat beberapa unsure penting yaitu mendidik dan mengajar, menjaga kesehatan, mengawasi perkembangan fisik, menyekolahkan, dan mengurus pernikahannya. Karena membangun chemistry yang kuat antara ayah dan anak sangat berpengaruh dalam kehidupannya kelak. Sehingga jangan sampai ada perubahan sikap terhadap anak yang sangat signifikan setelah poligami.

Persoalan yang muncul ketika poligami yang dilakukan tidak dicatatkan, hal tersebut berdampak buruk bagi anak dan bahkan terhadap pasangan suami istri tersebut. Perkawinan yang dicatatkan cenderung perkawinanya baik-baik saja meskipun tidak terlepas dari kemungkinan bahwa perkawinan monogamy yang dicatatkan pun mengalami permasalahan. Akan tetapi dengan adanya pertimbangan hakim yang mengabulkan permohonan poligami seseorang, menunjukkan bahwa adanya keyakinan yang kuat dari pemohon dapat melakukukan perkawinan poligaminya dengan baik, karena hal tersebut merupakan bukti bahwa pemohon pasti akan memberikan hak istri-istrinya dengan layak dan tepat bahkan kepada anakanaknya. Dalam memenuhi hak anak tersebut, tak terlepas dari bagaimana suatu keluarga berada dalam kualitas keluarga yang baik dimana dapat mencakup semua aspek yang merupakan dasar untuk mencapai keluarga sejahtera. Tidak hanya keluarga dalam perkawinan poligami bahkan dalam perkawinan monogamy pun kualitas keluarga harus diperhatikan.

Demi terwujudnya cita-cita Negara dalam upaya terwujudnya keadilan dan kesejahteraan anak dengan menjamin terpenuhinya hak-hak anak secara optimal, maka diperlukan adanya pembaharuan terhadap Undang-Undang No. 1 Tahun 1974 Tentang Perkawinan pasal 5 ayat (1) tentang persyaratan izin poligami. Hal tersebut dianggap perlu karena pemohon izin poligami hanya membutuhkan izin dari istrinya untuk melakukan poligami, sedangkan izin anak sama sekali tidak disinggung. Sedangkan di dalam keluarga itu tidak hanya terdapat suami dan istri saja, akan tetapi buah dari perkawinan itu yaitu anak, yang tidak boleh terabaikan keberadaannya. Sehingga perlu dan patut sekali jika pemohon izin poligami membutuhkan izin dari anaknya pula. 
Di dalam keluarga poligami yang baik, maka hak-hak anak terpenuhi dengan baik, sehingga dalam mencapai kualitas keluarga yang sejahtera pun tidak akan mengalami suatu kendala yang berat. Karena kualitas keluarga yang baik berada dalam kondisi keluarga yang mencakup aspek pendidikan, kesehatan, ekonomi, sosial budaya, kemandirian keluarga dan mental spiritual serta nilai-nilai agama yang merupakan dasar untuk mencapai keluarga sejahtera menurut Undang-Undang Nomor 52 Tahun 2009 Tentang Perkembangan Kependudukan dan Pembangunan Keluarga. Hal tersebut pun juga merupakan konsen dan maksud dari hukum Islam dalam mencapai keluarga yang bahagia serta dapat memenuhi hak-hak anak, karena di dalam hak-hak anak tersebut terdapat aspek pendidikan, kesehatan, ekonomi, sosial budaya, serta nilai-nilai agama yang merupakan dasar untuk mencapai keluarga sejahtera. Akan tetapi sasaran dalam peraturan perundang-undangan tersebut tidak hanya anak, akan tetapi seluruh anggota keluarga.

Dapat dipahami bahwa peraturan perundang-undangan pun mempunyai tujuan yang sama dengan hukum Islam dalam mewujudkan kehidupan anak yang lebih baik dan layak guna terpenuhi hak-hak anak, di dalam keluarga monogamy ataupun poligami. Jika kualitas keluarga tersebut tidak dapat dijaga, maka anak pun akan menjadi korbannya, dengan contoh salah satu keluarga poligami dimana suami tidak bisa membagi waktu dengan baik sehingga kualitas bahkan kuantitas pertemuan antara anak dan suami sangat berkurang yang akhirnya mempengaruhi kemerosotan nilai di sekolah, bahkan moral anak pun. Jika hal tersebut berlangsung terus menerus maka akan sangat mempengaruhi pola pikir anak yang berdampak bagi masa depannya.

Dalam kehidupan poligami seorang suami hidup bersama sejumlah istri dan anak-anak, bahkan mungkin dengan sejumlah anggota keluarga dari masing-masing istri. ketentraman masyarakat bersumber dari ketentraman dalam keluarga. Bagaimana mungkin timbul ketentraman dalam keluarga yang terdiri dari banyak istri dan banyak anak. Pandangan fiqih yang mengatakan bahwa dalam poligami suami tidak diwajibkan untuk berlaku adil dalam soal cinta, melainkan hanya dituntut pada hal-hal yang bersifat materi seperti nafkah. Karena tidak wajibnya berlaku adil dalam soal cinta, hal ini tidak mungkin dilakukan oleh suami manapun, maka suami sering kali mencintai salah seorang istri saja dan mengabaikan istri lainnya. Hal inilah yang memicu timbulnya berbagai konflik internal dalam kehidupan keluarga poligami. Konflik yang terjadi bukan hanya terbatas antara suami dan istri, melainkan meluas di antara anak-anak yang berlainan ibu, antara anak dan ayahnya, bahkan di antara anggota satu keluarga dan keluarga lainnya. Konflik-konflik tersebut akan muncul setiap saat, dan mungkin akan meredam tetapi pada saat yang lain akan sulit dibendung. Konflik internal dalam keluarga poligami tidak sebesar dan serumit pada keluarga monogami. Meskipun di dalam keluarga monogami juga ada konflik, tetapi pastilah konflik yang timbul tidak sehebat konflik dalam keluarga poligami yang sangat heterogen.

Kebahagiaan keluarga lebih mungkin diwujudkan dalam kehidupan perkawinan monogami daripada poligami. Karena dalam monogami, suami dapat mencurahkan seluruh emosi dan perhatiannya hanya kepada satu istri dan anak-anaknya. Lebih mudah baginya untuk memenuhi hak-hak istri dan anak-anaknya mencakup kasih sayang, perhatian, dan kebutuhan material. Hal yang sama sulit dilakukan pada kondisi perkawinan poligami.

\section{Kesimpulan}

Di dalam keluarga poligami yang baik, maka hak-hak anak terpenuhi dengan baik, sehingga dalam mencapai kualitas keluarga yang sejahtera pun tidak akan mengalami suatu kendala yang berat. Karena kualitas keluarga yang baik berada dalam kondisi keluarga yang mencakup aspek pendidikan, kesehatan, ekonomi, sosial budaya, kemandirian keluarga dan mental spiritual serta nilai-nilai agama yang merupakan dasar untuk mencapai keluarga sejahtera menurut Undang-Undang Nomor 52 Tahun 2009 Tentang Perkembangan Kependudukan dan Pembangunan Keluarga. Hal tersebut pun juga merupakan konsen dan maksud dari hukum Islam dalam mencapai keluarga yang bahagia serta dapat memenuhi hak-hak anak, karena di dalam hak-hak anak tersebut terdapat aspek pendidikan, kesehatan, ekonomi, sosial budaya, serta nilai-nilai agama yang merupakan dasar untuk mencapai keluarga sejahtera. Akan tetapi sasaran dalam peraturan perundang-undangan tersebut tidak hanya anak, akan tetapi seluruh anggota keluarga. 


\section{Daftar Pustaka}

Hal. 1 - 6

Az-Zuhaili, Wahbah. 2011. Fiqih Islam Wa adillatuhu. (Jilid 10). (Terj. Abdul Hayyie al-Kattani). Jakarta: Gema Insani.

Chatib, Munif. 2013. Orangtunya Manusia. Bandung: Kaifa.

Machali, Rochayah Machali et al. 2005. Wacana Poligami Di Indonesia. Bandung: Mizan.

Mahmasani, Subhi. 1993. Konsep Dasar Hak-Hak Asasi Manusia (Studi Perbandingan Syari'at Islam dan Perundang-undangan Modern). (Terj. Hasanuddin). Jakarta: Tintamas Indonesia.

Nizam. 2005. Kewajian Orang atua Laki-Laki (Ayah) Atas Biaya Nafkah Anak Sah Setelah Terjadinya Perceraian. Tesis Magister Kenotariatan yang tidak diterbitkan, Universitas Diponegoro, Semarang 2005.

Undang-Undang Nomor 52 Tahun 2009 